\title{
Comparison Of Achievement Sport Systems Between Indonesia And China
}

\author{
Muhammad Reza Aziz Prasetya \\ Universitas Negeri Surabaya, Surabaya \\ prasetyareza44@gmail.com
}

\begin{abstract}
Sport as a model of human creativity is a form of physical activity that has very complex dimensions, which undergo a systematic process in the form of all activities or efforts that can encourage, arouse, develop and foster one's physical and spiritual potential. as individuals or members of society. in the form of games, competitions/contests, and intensive physical activities to obtain recreation, victory, and peak potential. Sport is currently a trend or lifestyle for some of the general public, even to the point of becoming a basic need in life. National development through the development of sports in Indonesia in this reform era has become a strategic vehicle, especially improving the quality of human resources, as well as the formation of the character and character of the nation, in this paper many factors play a role in success in the field of sports, one of which the author wants to examine the differences and similarities between the performance sports system that runs in Indonesia and China. This study aims to compare the development of achievement sports systems carried out in Indonesia and China in order to improve the quality and competence of sports. This study uses a qualitative descriptive method with data collection techniques through documentation studies. The results of this study conclude that the government's contribution is needed in preparing winning strategies, training facilities, increasing competition opportunities and increasing resources that can be assisted by a team of academics and researchers from universities to find new techniques in training to support the maximum use of sport science.
\end{abstract}

Keywords: achievement sports system, Indonesia, China.

\section{Abstrak}

Olahraga sebagai salah satu model karya cipta manusia, merupakan suatu bentuk aktivitas fisik yang memiliki dimensi sangat kompleks, yang mengalami proses sistematis berupa segala aktivitas atau usaha yang dapat mendorong, membangkitkan, mengembangkan dan membina potensi jasmani dan rohani seseorang. sebagai individu atau anggota masyarakat. berupa permainan, kompetisi/perlombaan, dan aktivitas fisik yang intensif untuk memperoleh rekreasi, kemenangan, dan potensi puncak. Olahraga saat ini menjadi trend atau gaya hidup bagi sebagian masyarakat umum, bahkan sampai menjadi kebutuhan pokok dalam kehidupan. Pembangunan nasional melalui pengembangan olahraga di Indonesia pada era reformasi ini menjadi wahana yang strategis, khususnya peningkatan kualitas SDM, serta pembentukan watak dan karakter bangsa, dalam penulisan ini banyak faktor yang berperan dalam kesuksesan dibidang olahraga, salah satunya disini penulis ingin mengkaji perbedaan dan persamaan sistem olahraga prestasi antara yang berjalan di Indonesia dan China. Penelitian ini bertujuan untuk 
membandingkan perkembangan sistem olahraga prestasi yang dilakukan di Indonesia dan China dalam rangka peningkatan kualitas dan kompetensi olahraga. Penelitian ini menggunakan metode deskriptif kualitatif dengan teknik pengumpulan data melalui studi dokumentasi. Hasil penelitian ini menyimpulkan bahwa diperlukan kontribusi pemerintah dalam mempersiapkan srategi pemenangan, fasilitas latihan, menambah peluang kompetisi dan peningkatan sumber daya yang bisa dibantu oleh tim akademisi dan peneliti dari universitas untuk menemukan teknik-teknik baru dalam pelatihan untuk menunjang pemanfaatan sport science secara maksimal.

Kata kunci: sistem olahraga prestasi, Indonesia, China.

\section{Introduction}

Sport is a form of physical activity that can improve physical fitness, because sports do not only involve the musculoskeletal system but also include other systems such as the cardiovascular system, respiratory system, excretory system, nervous system and many more. If exercise is carried out with appropriate doses of intensity, duration and frequency, it will result in increased muscle work, endurance, reaction speed, maximum oxygen uptake, strengthens the heart muscle, controls blood pressure and pulse rate. Regular or regular exercise can be done every two days. Sport is currently a trend or lifestyle for some of the general public, even to the point of becoming a basic need in life. Sport is a very important need because it cannot be separated from the basic needs in carrying out daily motion activities. Sport itself is basically a series of regular and planned physical movements to maintain and improve the ability to move, and aims to maintain and improve one's quality of life. Sport as a model of human creativity, is a form of physical activity that has very complex dimensions, which undergo a systematic process in the form of all activities or businesses that can encourage, arouse, develop and foster the physical and spiritual potentials of a person as an individual or a member of society. in the form of games, competitions/competitions, and intensive physical activities to obtain recreation, victory, and peak potential in the context of forming a fully qualified Indonesian human being based on Pancasila (Cholik, 2002, p. 152).

Sport is part of physical activity. For adults, the weekly exercise target is 150 minutes of moderate-intensity physical activity or 75 minutes of vigorous-intensity physical activity. Moderate-intensity physical activity is light physical activity of 10-60 minutes per week such as table tennis and brisk walking. Strenuous physical activity is physical activity such as running 1.5 $<7.5 \mathrm{~km}$ per week or activities such as running. Physical activity is also defined as any body movement carried out by skeletal muscles that causes energy expenditure which includes various activities such as exercise, sports, play and active movement. Sports activities in each country are basically the same, namely used to meet practical needs in life because they have the attraction to develop various abilities, foster hope, provide development experience, improve physical fitness by involving the resulting muscle system to participation in sports activities (Muchtar, 2011).

One of the focuses of the Indonesian state in the development of sports activities is achievement sports. Today, the Indonesian nation is in a period of reform towards various important changes in the administration of the state as well as rearranging various development sectors in order to be able to successfully get out of a prolonged crisis ( $\mathrm{Ma} \& \mathrm{Wu}, 2020$ ). Even the crisis that occurred resulted in Indonesia being far behind with countries in the Asian region even though it already had a sports system that was implemented. It is still in our memory that at the 2008 Olympics in Beijing, Who was the overall champion at that time? Yes, indeed no one ever thought that China almost wiped out all the gold medals contested in every sport competed at the 
Olympics, even though under the shadow of the defending champion the United States. In fact, what has been done by the Chinese government in preparing its athletes through policies in sports practice that lasted continuously from the 1920s to 2000s with special emphasis on the Beijing Olympics (Wei et al., 2010). To face the biggest sporting event in the world, it was prepared through a long process by combining several fields, namely the fields of education, economics, social, industry, and specifically covering sports science, facilities, equipment, and sports medicine. Even the education and sports fields in China are in one department so that they are centralized and controlled under one supervision ( $\mathrm{Si}$ et al., 2015). National development through the development of sports in Indonesia in this reform era has become a strategic vehicle, especially improving the quality of human resources, as well as shaping the character and character of the nation. One of the tangible forms of national sports development in the reform era is the ratification and promulgation of Law no. 3 of 2005 concerning the National Sports System on September 23, 2005 .

The stipulation of a national sports law brings fresh air as well as a clear, structured, coordinated, coordinated and legal direction for the development of sports at the national level (Ring \& Kavussanu, 2018). The stipulation of national sports law, in addition to providing opportunities or prospects, also provides formidable challenges in the development of sports nationally. This is because the issue of sport has grown so complex, full of nuances of competition to politics, and if not managed systematically can lead to the opposite side of the main goal (Purba, 2008). Based on the description above, there are many factors that play a role in success in the field of sports, one of which is here the author wants to examine the differences and similarities between the sports achievement system that runs in Indonesia and China. The difference here does not mean to find out who is better, but can be used as material for study and information in the development of sports in the future.

\section{Methods}

This type of research is a comparative research with qualitative descriptive research methods that aim to find similarities and differences about objects, people, ideas, work procedures for people, groups or countries (Arikunto, 2010, p. 310). This research focuses on the similarities and differences between Indonesia and China in understanding, viewing and implementing the sports achievement system. The research subject in this comparative study is the achievement sports system implemented in Indonesia and China. The data used in this study are source documents, with data collection techniques carried out on research subjects through documentation studies by utilizing a collection of archives, which were disclosed by Shodiq \& Muttaqien in Strauss \& Corbin (Shodiq \& Muttaqien, 2003, p. 212). The data analysis technique was carried out using the analytical archive method so as to facilitate the search for information and thoughts

\section{Result and Discussion}

Achievement sports will continue to develop in the traditional 'Juguo Tizhi' form where the whole country supports the merit sports system for its political and patriotic purposes (Wei et al., 2010). The following comparison between sports achievements in Indonesia and China is presented in table 1.

Table 1. Comparison of Achievement Sports Systems in Indonesia and China 


\begin{tabular}{lcc}
\hline \multicolumn{1}{c}{ Aspect } & \multicolumn{2}{c}{ Achievement Sports System Comparison } \\
\cline { 2 - 3 } & Indonesia & China \\
\hline $\begin{array}{l}\text { First Participation in the } \\
\text { Olympics }\end{array}$ & 1952 & 1952
\end{tabular}

Olympic Winning The government concentrates Strategy

Performance administration system on sports and athletes who have passed the qualifications through intensive training sports Centralized and decentralized administration management systems

The government concentrates on preparing the best resources that have the potential to get a gold medal through special treatment and intensive training

Centralized administration and management system

Competition

Opportunities
Competitions in Indonesia for achievement sports are adjusted to the national and international calendars.

Training and Sport Trainers in Indonesia have Science
Competitions in China for merit sports are held every 4 years according to the Olympics not run professionally

The absence of sport science in supporting the development of sports achievements
Trainers in China from regional to national work professionally, even many are contracted by other countries

Academics and researchers at the university also contribute directly or indirectly to training, both in engineering, coaching, sports psychology, sports medicine, exercise physiology and biomechanics and sports sociology.

Training activities are Provincial, district and commission carried out under the control sports teams have the responsibility of the central sports team of nurturing and training elite athletes for the national team and awarding 
Training Facilities

Selection of sports

Competition Preparation

To face the Olympics has not been structured in a longterm program

Focus on sports that have the potential to earn medals as a whole in one coaching center

Most of the national sports are adapted to the Olympic sports and the existing regional potential. them when they win championships

China has more than 20 potential sports coaching centers

National sports are mostly adapted to the Olympics

To face the Olympics, national level competitions have been well structured.

Focus on the sports that are competed in the Olympics, from national to international levels, from senior teams to junior teams.

The development model of competitive sports in China underwent several changes in government functions during the 3 stages between 1949 and 2012 in several fields (Shodiq \& Muttaqien, 2003, p. 212). The development of sports policy in China has always been shaped by political, economic and educational requirements. Since the beginning of reform and opening up in the late 1970s, sporting achievements have received more support from the government while community sports are expected to be supported by the community itself (Ma \& Wu, 2020).

Broadly speaking, there are not many differences between the systems implemented in Indonesia and China. Both in 1952 as the first Olympics to be followed, the administrative system used is also centralized, only in Indonesia it combines centralization and decentralization for sports achievements. Competition opportunities in Indonesia are adjusted to the national and international calendars, while China is adjusted to the Olympic calendar, so for long-term goals it is more well structured. This can be seen in the Chinese government's focus on sports competed in the Olympics, from national to international levels, from senior teams to junior teams. Unlike in Indonesia, which only focuses on sports or individual athletes who have already declared qualification for the Olympics. The striking difference is seen in the Olympic winning strategy and the training facilities used, as well as the support of human resources that play a role in preparing athletes. 
The Indonesian government concentrates on sports and athletes who have passed the qualifications through intensive training with the support of coaches in Indonesia who have not run professionally. Why not professional yet? Because there are many trainers who are still doing other things outside the field of achievement sports, for example being active in the management of an organization, being active in government agencies, and so on. Meanwhile, the Chinese government concentrates on preparing the best resources that have the potential to win gold medals through special treatment and intensive training supported by professional training personnel and a team of academics and scientists/researchers. Why say professional? Because the government gives full trust to the trainers who have been appointed to show their performance within a certain period of time, and will be evaluated. Therefore, the trainers work professionally and compete to be able to show the best results in improving sports performance .

Likewise with training facilities. Achievement sports training facilities in Indonesia are still general for potential sports branches as a whole in one coaching center. There is almost no difference between club, regional and national level coaching centers. Meanwhile, achievement sports training facilities in China are carried out in coaching centers with more than 20 potential sports coaching centers.

\section{Conclussion}

Based on the results of a review of eight aspects that are considered to play a major role in the development of the sports achievement system in Indonesia and China, it is concluded that the government's contribution is needed in preparing winning strategies, yutraining facilities, increasing competition opportunities and increasing resources that can be assisted by a team of academics and researchers from universities to find new techniques in training to support the maximum use of sport science.

This research can be a reference in further research, and can be a reflection for readers and can also be developed better than the previous one

\section{References}

Arikunto, S. (2010). Prosedur Penelitian: Suatu Pendekatan Praktik. Jakarta: Rineka Cipta.

Cholik, T. (2002). Gagasan-Gagasan Tentang Pendidikan Jasmani dan Olahraga. Surabaya: Unesa University Press.

Ferdy Irawan, Y., \& Limanto, D. (2021). Pengaruh Kecerdasan Emosi dan Kesiapan Diri Terhadap Pertandingan Pada Pemain Walet Muda Futsal Academy Kebumen Tahun 2020. JUMORA: Jurnal Moderasi Olahraga, 1(01), 18-26. https://doi.org/10.53863/mor.v1i01.130

Fitria. (2013). 済無No Title No Title. Journal of Chemical Information and Modeling, 53(9), 1689-1699.

Guntur Sutopo, W., \& Misno. (2021). Analisis Kecepatan Tendangan Sabit Pada Pesilat Remaja 
Perguruan Pencak Silat Tri Guna Sakti Di Kabupaten Kebumen Tahun 2020. JUMORA: Jurnal Moderasi Olahraga, 1(01), 27-34. https://doi.org/10.53863/mor.v1i01.131

G,. D., Wu, Y., \& Dai. Z. (2015). A Study of The Change in Governent Functions in Elite Sport Development in China, 1949-2012. The International Journal of the History of Sport, 32(10), 1353-1357. https://doi.org/10.1080/09523367.2015.1066993

Ma, G., \& Wu, Q. (2020). Cultural capital in migration: Academic achievements of Chinese migrant children in urban public schools. Children and Youth Services Review, 116(18), 105196. https://doi.org/10.1016/j.childyouth.2020.105196

Muchtar, A. T. (2011). Kebangkitan dan Kebijakan Luar Negeri Cina: Antara Persepsi dan Pilihan. Maarif, 6(2), 28-58.

Purba, J. P. (2008). Sistem Pendidikan Jasmani Dan Olahraga.

Ring, C., \& Kavussanu, M. (2018). The impact of achievement goals on cheating in sport. Psychology of Sport and Exercise, 35(June 2017), 98-103. https://doi.org/10.1016/j.psychsport.2017.11.016

Shodiq, M., Muttaqien, I. (2003). Dasar- Dasar Penelitian Kualitatif. Yogyakarta: Pustaka Pelajar.

Si, G., Duan, Y., Li, H. Y., Zhang, C. Q., \& Su, N. (2015). The influence of the chinese sport system and chinese cultural characteristics on olympic sport psychology services. Psychology of Sport and Exercise, 17, 56-67. https://doi.org/10.1016/j.psychsport.2014.08.008

Wei, F., Hong, F., \& Zhouxiang, L. (2010). Chinese state sports policy: Pre- and Post-Beijing 2008. International Journal of the History of Sport, 27(14-15), 2380-2402. https://doi.org/10.1080/09523367.2010.504583 